\title{
Aliando o Patrimônio Cultural ao Geopatrimônio: um roteiro geoturístico costeiro no município de Cabedelo, Paraíba (Nordeste do Brasil)
}

\author{
Allying the cultural heritage to geoheritage: a geotouristic coastal itineray in the municipality of Cabedelo, Paraíba \\ (northeast of Brazil)
}

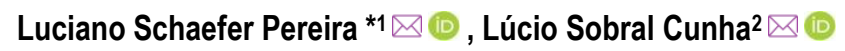

1'nstituto Federal de Educação, Ciência e Tecnologia da Paraíba, Campus João Pessoa,

Paraiba, Brasil

Recebido (Received): 19/02/2021

2Faculdade de Letras, Departamento de Geografia, Universidade de Coimbra, Portugal

E-mail: Ischaefer2@gmail.com

*E-mail para correspondência: luciogeo@uc.pt

Resumo: A dinâmica marinha em ambiente costeiro, entrelaçada ao fluxo turístico, o torna uma área de conflito e instabilidade, aumentando, ainda mais, os impactos ambientais deletérios. Desse modo, o espaço requer um planejamento rigoroso para amenizar os riscos. Por outro lado, a partir de valores como o estético e o científico, os ambientes costeiros, paradoxalmente, possuem um grande potencial geoturístico, próprio de sua dinâmica natural, normalmente pouco explorado, especialmente no Brasil. O Município de Cabedelo, no Estado da Paraíba, corresponde a uma extensa restinga margeada, a leste, pelo Rio Paraíba e, a oeste, pelo Oceano Atlântico. O presente artigo propõe um roteiro geoturístico que inclui quatro locais de interesse: Areia Vermelha, um banco de areia que emerge nas marés baixas, depositado sobre arenitos praiais; as Ruínas de Almagre, de origem jesuítica, datadas do século XVI, construídas com calcário e arenitos ferruginosos; a Fortaleza de Cabedelo, remanescente do triângulo defensivo construído, a partir do final do século XVI, pelos portugueses e que utiliza os mesmos georecursos de Almagre e; a Praia do Jacaré, uma praia fluvial, de onde é possível observar extensos manguezais, em sua margem direita e largos terraços fluviais, preenchidos por cana-de-açúcar, na margem esquerda.A existência de roteiros geointerpretativos assinam uma nova função aos itinerários, agora com vies geoturístico, ao enriquecer a experiência dos turistas, oferecendo a oportunidade de conhecer o meio abiótico e cultural de uma outra perspectiva, sem esquecer da necessária consciência ambiental.

Palavras-chave: Geodiversidade; Geointerpretação; Valor Cultural; Cabedelo.

Abstract: The coastal environment is an area of conflict, where the marine dynamics intertwine with the tourist flow, originating, from the environmental point of view, an unstable space, in which the impacts are potentially bigger. Due to this, it requires a intense planning aimed at its protection. Paradoxically, coastal environments are areas of great geotouristic potential precisely for this natural dynamics that gives them its scientific value. The municipality of Cabedelo, State of Paraíba, corresponds to an extensive sandbank bordered to the west by the Paraíba River and to the east by the Atlantic Ocean. This article proposes a geotouristic itinerary that includes four places of geotouristic interest. These places of interest are: Red Sand, a sandbank, deposited on beach sandstones, which emerge at low tides; the Ruins of Almagre, remains of a Jesuit church, dating from the $16^{\text {th }}$ century, built with limestone and ironstone; the Fortress of Cabedelo, remnant of the defensive triangle built by the Portuguese, in the end of the $16^{\text {th }}$ century, which used the same geo-resources present at Almagre and; Jacaré Beach, from where it is possible to observe extensive mangroves, on its bank, and large river terraces, filled with sugar cane fields, on the opposite bank. The existence of interpretative trails assigns a new function, now from the geotouristic point of view, to the itineraries, as they enrich the experience of tourists, to whom is given the opportunity of knowing the abiotic heritage and the cultural heritage from another perspective, apart from enhancing their environmental awareness.

Keywords: Geodiversity; Geointerpretation; Cultural Value; Cabedelo. 


\section{Introduction}

Geotouristic itineraries are routes, accessed on foot or through vehicles, which include a set of places that have high scientific, cultural, aesthetic, functional and economic value, among others, and that involve both cultural heritage and geoheritage. It is also through them that Geosciences are disseminated and promoted.

The valorisation of physical and cultural aspects in geotouristic activity is a form of creating interaction between the community and the environment that surrounds it, through the discovery and appreciation of elements in the landscape, until then ignored.

As for the abiotic environment, the geotouristic itineraries are important tools for the dissemination of Geosciences because they work as an outdoor field class that assists in the learning about the physical phenomena associated with the landscape. In relation to the cultural environment, it involves the historical record and the characteristics of the georesources used in the construction of assets. By knowing and mapping cultural heritage, including churches, houses, cemeteries, monuments, paved roads, among others, by describing architecture and history, by identifying the lithologies, by characterizing stone materials and, if possible, by identifying origins, it is possible to recommend measures that encourage and guarantee its geoconservation and promote its geodiversity. (PEREIRA et al., 2013; PEREIRA; AMARAL, 2014).

The geotouristic itineraries disseminate and promote the appreciation of geoheritage, relating it to civilizations and cultures. They consist of the addition of geoheritage elements to tourist activities, focusing on places of geotouristic interest, which favour local communities and provide visitors with a new tourist experience.

The urban coastline of the Cabedelo city has numerous tourist spots which are among the most visited in the Paraíba State. However, the tour guides exclude, due to the lack of information, the abiotic aspects of the landscape. The proposal of the geotouristic itinerary of this area highlights these aspects, seeking to use a language easily understood by the majority of tourists, even those with little knowledge.

Geotouristic maps mix elements of geoscientific information, related with geodiversity and geoheritage per se, with cultural and tourist features so that the public can easily interpret them. Therefore, due to the presence of more complete tourist infrastructures, particularly road networks and parking facilities, basic tourist information is prioritized.

The proposed itinerary is based on the concept of Geotourism by Pereira (2019) as "an activity that is located in the interface of nature tourism and cultural tourism, always with knowledge as the main motivation. It can be developed both in environments where natural aspects prevail and in urban settings, disseminating and promoting geodiversity and its geoheritage, in a more restricted sense, or its relationship with civilizations and cultures, in a broader sense, all in a sustainable manner".

Thus, geotourism works as a mechanism for the development of a sustainable activity, contributing to the geoconservation and dissemination of its geoheritage and cultural heritage. These improve the quality of life of the population, generating funds through the allocation of new values and meanings to the area where it is developed and encouraging the sense of cultural identity by increasing the awareness of the local population and visitors of this patrimony.

The itinerary includes two buildings belonging to the early occupation of the area (the Ruins of Almagre and the Fortress of Cabedelo, both listed by IPHAN - the National Historic and Artistic Heritage Institute of Brazil) and two geoheritage places of interest, one geological (Areia Vermelha - Red Sand) and one geological/geomorphological/hydrological (Praia do Jacaré - Alligator Beach). The aim of this proposal is to disseminate the physical aspects of the landscape (geology, geomorphology and hydrology) and the historical-cultural aspects of the assets, in order to contribute for their maintenance and preservation.

\section{Methods}

The itinerary, the baseline of this article, corresponds to a final phase of the promotion process involving other sequential phases (BRILHA, 2005), namely: identification (in which geoheritage segment can the site be inserted? Geological, geomorphological, pedological or hydrological?); inventory (creation of a database with the heritage elements, with the completion of descriptive files, containing various information, such as absolute location, means of access, photographic register of the site, a detailed description of geological, geomorphological, pedological and hydrological features, considering the scale of the site, from the outcrop to the landscape); semi-quantitative evaluation (degree of importance of the element for geotourism, as well as the evaluation of the degree of vulnerability, aiming at the creation of geoconservation measures, based on 
Pereira et al., 2019); and promotion (publicity of the value of heritage elements, through the elaboration of this Geotouristic Itinerary, one of several that will be published later).

This integrated The QGIS software version 3.0 (Girona) was the operational technique used to create the geotouristic itinerary, using the vectorization of the elements of interest from the coverage area of the study. Google Earth image mosaic was used as a base for this, with the application of the Quick Map Services module. The vector layers used in the elaboration of the maps were applied using the geographical coordinate system DATUM WGS 84 (EPSG 4326 Code).

The geographical scales used in the itineraries varied according to the spatial area of the different maps, so that these could be allocated in their pre-defined layout. The scale of the map was 1: 5,000, but it was considered as a detailed scale map.

\section{Characteristics of the study area}

The Cabedelo Municipality has a population of 57,944 inhabitants (IBGE, 2010) in an area of 31,915 $\mathrm{km}^{2}$, which results in a demographic density of 1815.6 inhabitants $/ \mathrm{km}^{2}$, the second largest in the State, only inferior to João Pessoa, capital of the State. It corresponds to an immense sandbank, $18 \mathrm{~km}$ long and $3 \mathrm{~km}$ wide, bathed to the west by the Paraíba River. It is bordered to the south with João Pessoa and to the north, with Lucena, after the mouth of the Paraíba River, and to the west, with the Santa Rita city, after crossing the aforementioned river (Figure 1).

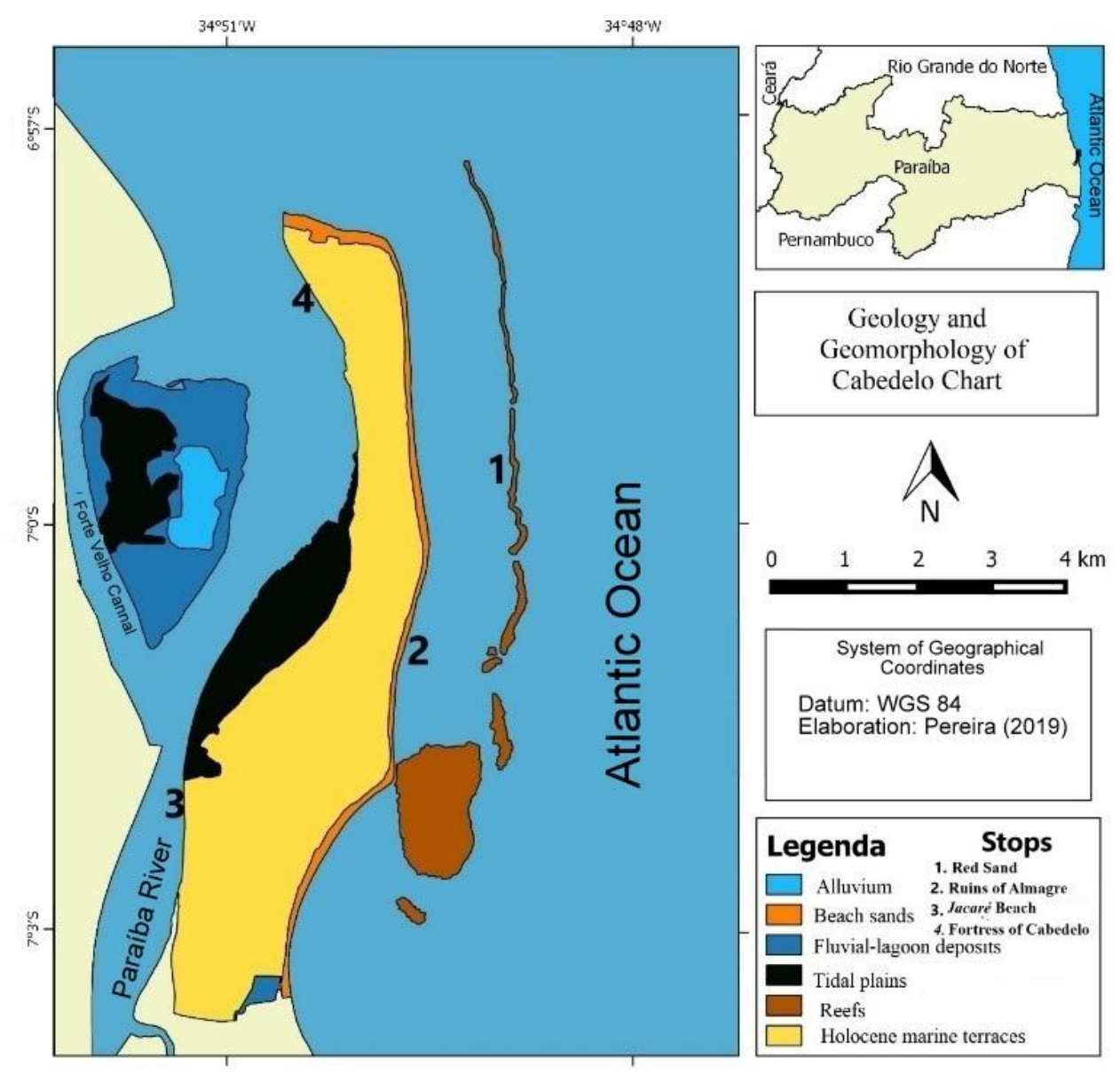

Figure 1: Geologic and geomophologic map of Cabedelo.

It was the first colonial settlement of the State, before the foundation of Nossa Senhora das Neves, and it served as a base for the Portuguese to enter the Paraíba River and settle where João Pessoa is located today. The defensive triangle of the Paraíba River estuary was built in its area; it consisted of the Fort of Santo António, the Fort of Cabedelo Santa Catarina and the Fort of Restinga (PINTO, 1977).

The Restinga of Cabedelo is a Holocene marine terrace, $13 \mathrm{Km}$ wide. The Holocene terraces consist of sandy deposits, no more than $4 \mathrm{~m}$ above the current high tide, which were formed during the marine regression following the Last Transgression (BITTENCOURT et al., 1979) or Santos Transgression 
(SUGUIO; MARTIN, 1978), between 5 and 7 ka BP (MARTIN et al., 1979), according to studies on the quaternary deposition along the coast between Rio de Janeiro and Alagoas State.

In the urban coastal zone of Cabedelo, the terraces have important physical-environmental characteristics. They are densely occupied by urban neighbourhoods that have the most expensive square metre in the state. They represent the coastal plain, being separated from the coastal strips by a continuous line of inactive forested cliffs, whose limits can be easily discriminated as they can be observed at a long distance, especially in the north sector. They are also important indicators of coastal dynamics, especially in the last $7 \mathrm{ka}$.

They consist of unconsolidated quartz sands, with light tones, fine granulometry, moderately selected, with plane-parallel stratification (ALHEIROS et al., 1990) and predominantly fine granulometry (FURRIER, 2007).

In a dating procedure, using the C-14 method and applied to lagoon sediments in the northern coast of the State of Sergipe, the results yielded an age of $7.2 \pm 200 \mathrm{ka} \mathrm{AP} \mathrm{(BITTENCOURT} \mathrm{et} \mathrm{al.,} \mathrm{1983),} \mathrm{while} \mathrm{shells}$ integrated in these terraces on the coast of Alagoas yielded ages between $2.57 \pm 170 \mathrm{ka} \mathrm{AP}$ and $3.69 \pm 180$ ka AP (BARBOSA et al., 1986).

The beaches of the Cabedelo Municipality have, in general, an open cove shape. From the Areia Dourada Beach to the mouth of the Paraíba River, the coast has a straight-line shape, which culminates at the Miramar Beach. From Ponta de Campina to the estuary of the river, a line of beach rocks parallel to the coastline points out to a small coastal paleo-line, about $1 \mathrm{~km}$ in the foreshore and about $10 \mathrm{~km}$ long, that characterizes Areia Vermelha, as well as sandbanks, particularly in the vicinity of the estuary of the Paraíba River. This entire coastline is stable in terms of the sediment balance (NEVES, 2003).

Analysing the beach segment of the municipality, from the point of view of morphology and sediment balance, it is possible to conclude that, where there is a continuous sediment supply and there is a tendency for the position of the coastline to prograde, as is the case, for example, of the majority of the beaches located in Restinga of Cabedelo. The backshore of the sandbank is intensely and disorderly occupied by buildings and engineering works, such as the Jaguaribe River channelling, among others. On some beaches, for example, retention structures were built to minimize the effects of the advance of the coastline, when in fact it was anthropic action that, through uncontrolled urbanization and poorly developed public policies, went too far on the beach.

\section{Proposed Geotourism Itinerary}

The proposal presented herein involves a geotouristic itinerary consisting of four places of interest: Areia Vermelha (Red Sand), Ruins of Almagre, Fortress of Cabedelo and Praia do Jacaré (Alligator Beach), according to Figure 2.

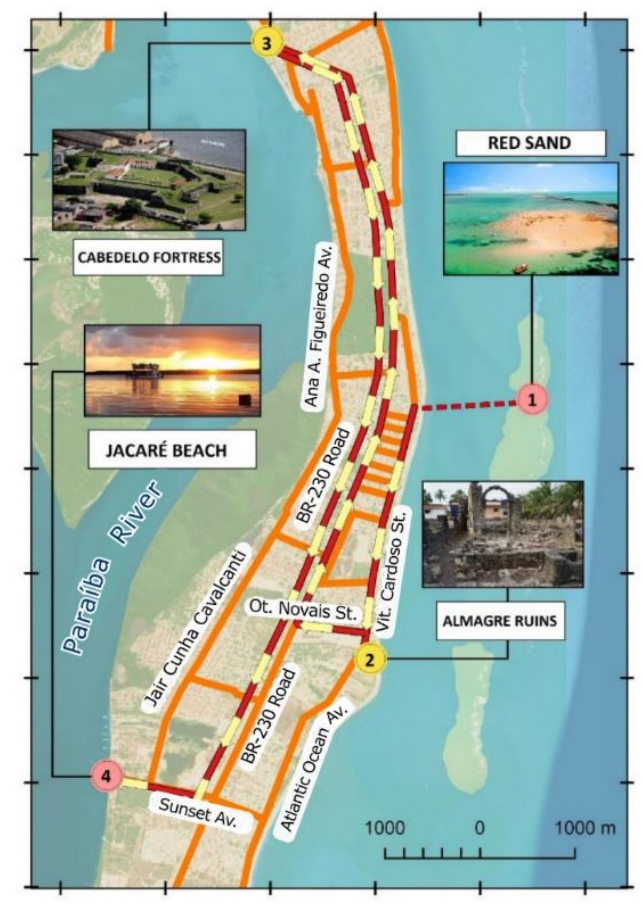

Figure 2: Geotourist itinerary in the Cabedelo coast. 


\subsection{1st Stop: Areia Vermelha (Red Sand)}

Areia Vermelha is the name of a sandbank, deposited on beach rocks, which emerge at low tides, located at about $1000 \mathrm{~m}$ from the coast. The access is done through the Camboinha Beach, in Cabedelo, from where several boats, speedboats, catamarans and "banana-boats" depart every day, taking hundreds of tourists (Figure 3), who can stay on the "island" for as long as they want. It has been a tourist attraction since the mid-1990s and it is part of the State Park of Areia Vermelha, established, in August 2000, by state decree (PARAÍBA, 2000).

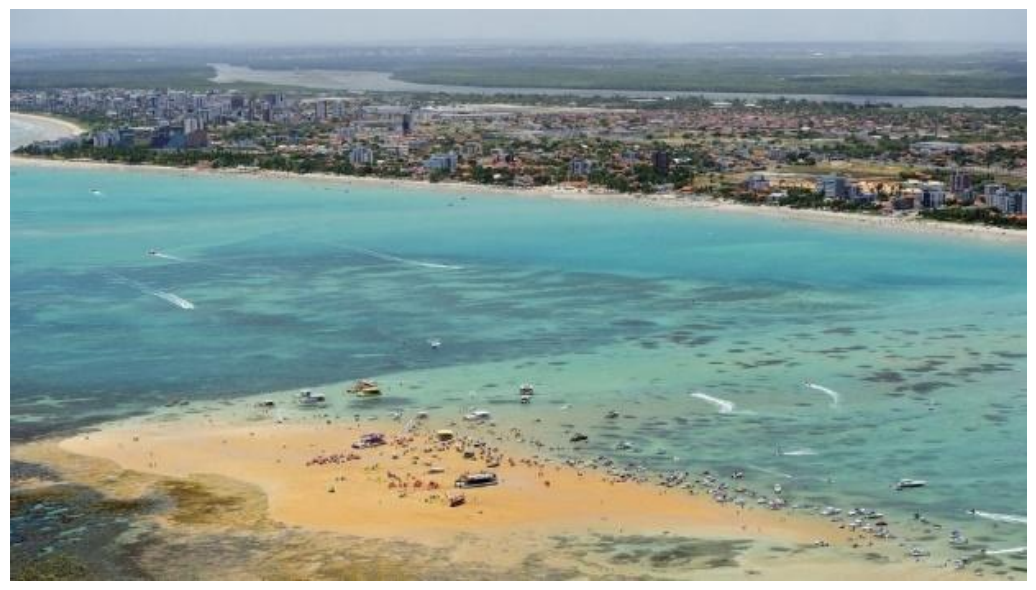

Figure 3: Aerial shot of Areia Vermelha. Photo: Hotelhardmann site.

This sandbank was deposited on a vast surface of beach rocks that mark the landscape and on which algae-coral reefs were formed. Therefore, it corresponds to an ecosystem that mixes geological elements (sandstones) and geomorphological elements (sandy surface) with a reef ecosystem that supports crustaceans, fish, molluscs, and corals, among other organisms. Apart from the Areia Vermelha Island, the Areia Dourada Island is also part of the Park, being located more to the north and has a smaller dimension.

The pioneer and systematic works written about these rocks date back to Branner (1904), although Darwin researched some of the outcrops in Recife and Rio de Janeiro, during his brief passage through Brazil, in 1832 (MANSUR, 2010; GUIMARÃES et al., 2016). The proposal of a beach origin (HARTT, 1870) for these elements was later on replaced by the foreshore origin (MABESOONE, 1964). Thus, the name "beach rock" was altered to "reef sandstone". Dominguez et al. (1990) criticized this because the denomination "reef" was associated with organic constructions. Dominguez et al. (1990) proceeded to suggest the term "sandstone banks" as being more appropriate. Currently, the designation "beach rock" has returned to literature in the context of rocky reefs (SUGUIO, 1992).

The designation "beach rock", used in this work, will be synonymous with "beach sandstone" for two reasons: i) it refers to the fact that these bodies originated from sandy sediments and were consolidated by calcium carbonate; ii) their linearity and mineralogical and texture characteristics corroborate with the beach geographical origin.

Part of the beach sandstones were formed in an environment with a higher sea level than the current one, which explains the fact that today they emerge during low tides. In Pernambuco and Paraíba, some vermintide gastropods incorporated into these beach sandstones were radiometrically dated. The results showed ages between $6.9 \mathrm{ka}-2.8 \mathrm{ka} \mathrm{BP}$, with five of the six samples above $5.5 \mathrm{ka}$ (BARRETO et al, 2010 and SUGUIO et al., 2013), higher than the age of $4.83 \pm 210 \mathrm{ka}$ proposed by Dominguez et al. (1990). Two samples of bivalves, dated from Paraíba, located on the northern coast of the State, bordering Rio Grande do Norte, yielded ages around $6.0 \mathrm{ka}$. If the sandstones of the Park have a temporal similarity with the sandstones of the north coast, it is possible to conclude that the lithification occurred at a time that marks a marine transgression after its formation since, considering the curve of relative sea level change obtained in these dates, between $5 \mathrm{Ka}$ and $4 \mathrm{Ka} \mathrm{AP}$, the sea level rose to its maximum, reaching almost 3 metres above the present level.

At the Place of Interest, the deposits are formed by quartz sandstones, in which quartz and K-feldspar reach $80 \%$ of the body, with fine to medium granulometry, moderately selected, sub-angular grains, cemented by calcium carbonate and presenting low angle and striated plain-parallel cross stratification. About $5 \%$ of the body is formed by bioclasts, mainly algae and foraminifera fragments and the rest carbonate cement. According to Mabesoone (1964), the carbonate cement originated from the dissolution of the 
carbonate from the sands when in contact with fresh and saline water, with the precipitation of calcite causing the lithification of the sandy sediment. Considering that calcite normally precipitates from fresh water, unlike aragonite, which requires solutions with high ionic potential (KOMAR, 1998), this is also evidence that the beach is the origin of these deposits.

Silva et al. (2017) produced thin sections from the rocks of Natal and classified them as arkoses, with a loose exterior and a core composed by minerals of monocrystalline quartz, plagioclase and microcline, with bioclasts of red algae, and muscovite, titanite, apatite and epidote as secondary minerals. The grains of the core are surrounded by fibrous fringes, which penetrate the fractures or replace part of the grains, cemented by cuticles with microcrystalline texture.

The beach sandstones crop out along the coast of all the Paraíba Basin, sometimes directly on the beach, forming linear features, continuously or not, for several kilometres, usually parallel to the coast. In general, they are underwater but they may become visible during low tides or emerge at medium sea level. The Park has a linear geometry, with a maximum extension of about $3 \mathrm{~km}$, a width that varies between 150 and 300 metres and thicknesses calculated between 0.5 and 1.5 metres. The surface is flat, with a slope of inferior to $8-10^{\circ}$, towards the ocean.

By forming continuous lines that may or may not emerge at low tides, they end up being responsible for the partial dissipation of wave trains that fall on the coast, playing a crucial role in their outline and promoting the navigability of ships.

In this context, an variety of maps and historical documents, dating from the $17^{\text {th }}$ and $18^{\text {th }}$ centuries, were made, with the sandstones being called 'barreta'. Nieuhof (1942) described these structures as being

[...] reefs or rocks that, in their majority, line up about half a mile from the beach. This makes the waters between them and the land very calm and allows maritime traffic, even during storm seasons, when navigation becomes almost impossible away from these cliffs, due to the violence of the current, coming from the north, and the south wind that blows there continuously (NIEUHOF, 1942, p. 52).

Curiously, due to its distance from the coast, they were not used as georesources for the monuments built along the coast, during the colonial period, like the Fortress of Cabedelo and the Church of Almagre. This is different from what occurred in Recife and Natal, to mention two nearby capitals, where the outcrops are closer to the coast. However, they had a fundamental role as barriers for the anchorage of large ships, also hindering the access to the mouth of the Paraíba River, which made it sheltered, according to the document previously mentioned.

Due to its exceptional functional value combined with its very high aesthetic, scientific and cultural values, Areia Vermelha is an important representative of the coastal geoheritage of the Cabedelo Municipality.

\subsection{2nd Stop: Ruins of Almagre}

The ruins of the Church of Nossa Senhora do Nazaré of Almagre are located on the edge of the beaches of Ponta de Campina and Poço, from the municipality of Cabedelo, with access through Vitorino Cardoso Street, continuation of Oceano Atlântico Avenue, direction João Pessoa - Cabedelo, 2300 metres after the entrance to the Intermares Neighbourhood. They were selected as a Place of Interest for both their cultural heritage and the presence of ironstone in their construction, something rare among the monuments of the area of study. The word "Almagre" (al-magrâ, from the Arabic) means reddish clay.

The origin of the temple is still uncertain, mainly due to the lack of historical documents, both textual and iconographic. The construction of the church may be dated between the end of the $16^{\text {th }}$ century and the beginning of the $17^{\text {th }}$ century, with Mello Neto and Mello (2000, apud OLIVEIRA, 2002) suggesting a Jesuit origin, near a village of indigenous converted Tabajara. Later, Franciscans assumed the church until 1740, when they were replaced by the Benedictines, who began repairing its walls. Like most of the construction works of the time, its prototype was probably built in taipa (rammed earth) and later added with stone masonry.

Mello Neto and Mello (2000, apud OLIVEIRA, 2002), using old photos, delimited the original plan of the church and the shape of the façade. Figure 4a shows the current situation of the main façade, with the model of the authors' proposal, while figure $4 \mathrm{~b}$ shows the current interior of the church. The church is formed by a main nave, surrounded by two smaller chambers with access to the choir on the upper floor, 
from which the one to the right still stands, two side doors decorated with scallops, with the right one still keeping the upper tribune preserved, side altars, a cross arch, giving access to the main altar, with an acanthus leaf on top and columns in stonework and, in the background, the main altar, whose surrounding walls are cluttered on the floor, and, further down, the lavatory of the sacristy.

As main geological resources, there are the Maastrichtian limestones of the Gramame Formation, predominant, and the Plio-pleistocene ironstones of the Barreiras Formation. The limestone is relatively pure, solid or laminated, some with fossils (shells) and with features of dissolution, being used as the main material of the internal walls, with the exception of some sandstone niches, as the ones next to the left door of the nave (see figure $\mathbf{4 b}$ ). The limestone is most probably from the quarries existing on the slope of the strips of the historical centre, since these two facies (solid and laminated) also appear in that lithology.
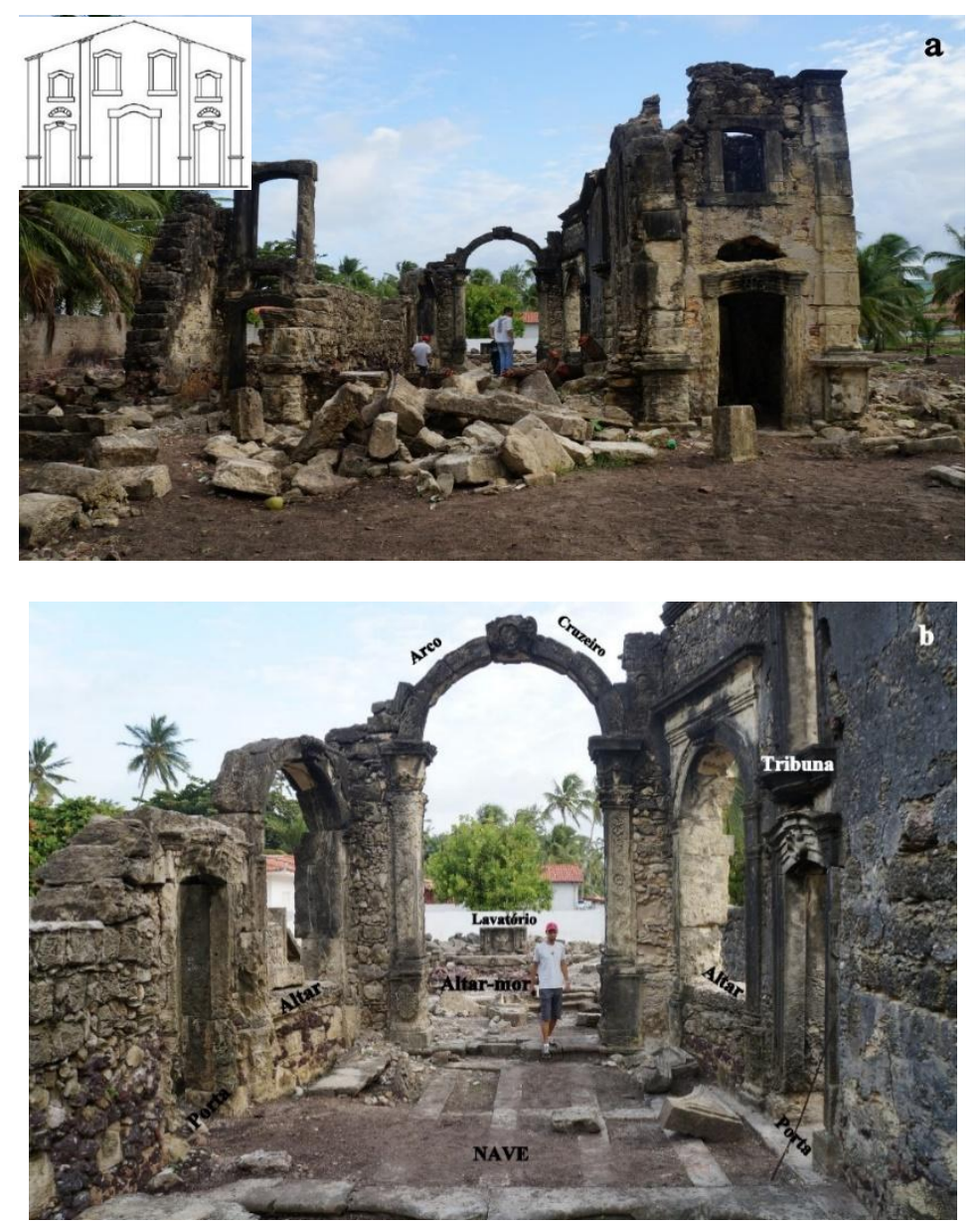

Figura 4: Ruins of Almagre. a) View of the front facade and, in detail, model of the complete facade. Note that the tower wedges are in danger of collapse; b) Detail of some internal components of the church. Photos: the author.

The sandstones probably came from the south coast, with the largest agglomeration occurring in the walls of the main altar. They consist of poorly consolidated sandy sediments, with characteristics of fluvial environment, in which the matrix is predominantly sandy, with larger grains of quartz and K-feldspar, subangular to sub-rounded, with low sphericity, this last mineral being altered to a greyish clay. They present plane-parallel stratification.

Several masonry walls, mainly the external ones, present a heterogeneous mixture of fragments of tiles and rows of ceramic bricks next to the blocks of limestone and sandstone, serving as fillers or as levelling layers, cemented by a mortar composed of sand and lime. The clay used to make the bricks may have come from the various nearby alluvia or even from the Paraíba River, 2500 metres away from the site.

\subsection{3rd Stop: Fortress of Cabedelo Santa Catarina}

The Fortress of Cabedelo is located at the mouth of the Paraíba River, on its right bank, in the final portion of the Restinga of Cabedelo, being the Port of Cabedelo, its northern neighbour. 
Currently, the Fortress is one of the main tourist points of the coast of Paraíba, possessing a museum, an art gallery, a studio, a souvenir shop, among other places worthy of a visit (figure 5). Therefore, due to its cultural and historical value, the IPHAN -National Institute of Historic and Artistic Heritage of Brazil put the Fortress under public tutelage, in 1938, through the decree no. 155.

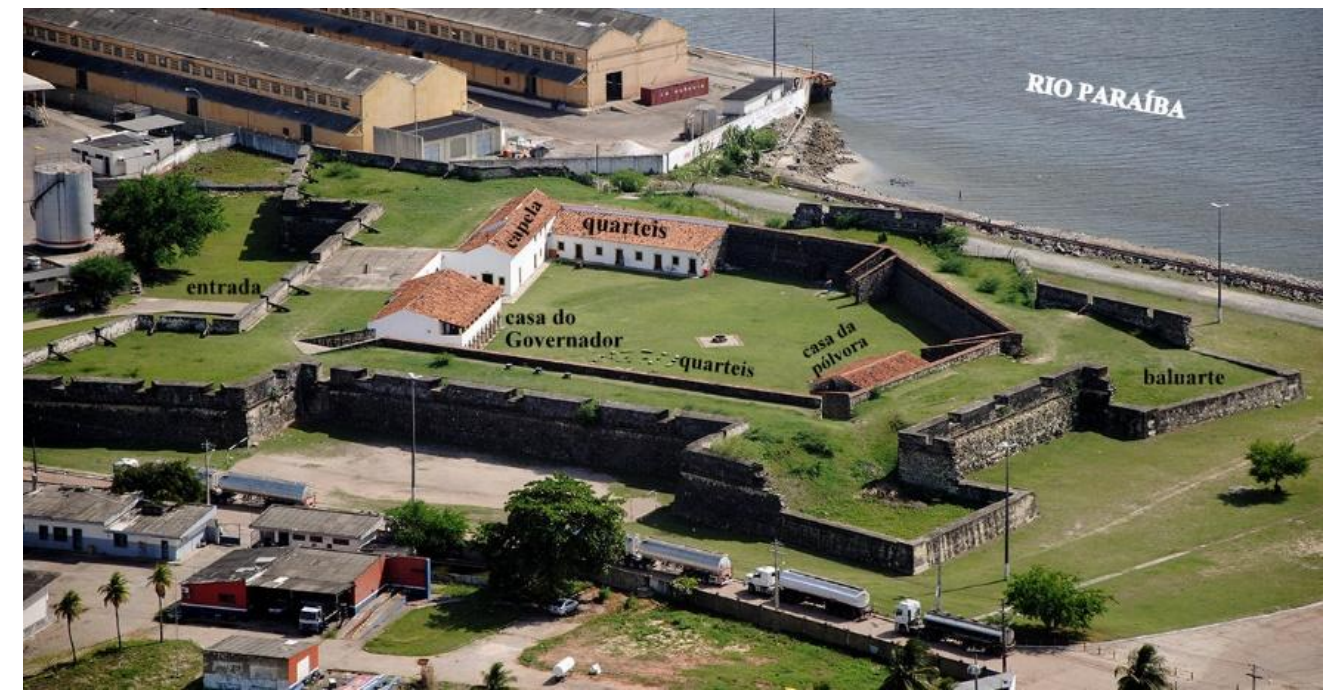

Figura 5: Aerial shot of Cabedelo Fortress. North to the right. Photo: modified from Cabedelo City Hall.

It was through this river mouth that the conquest and settlement of the Captaincy of Paraíba took place, hence its historical importance as part of the defensive triangle that protected the emerging city in the mid$16^{\text {th }}$ and $17^{\text {th }}$ centuries. The Fortress of Cabedelo is one of the most important historical-architectural monuments in the area. It is the result of the historical valorisation of the Holocene marine terrace, near the estuary of the Paraíba River, whose site was strategically selected as a defence point for offering excellent views over the lower course of the river and valley and a wide panorama of the ocean ahead.

Its construction, in taipa (rammed earth), dates from the 1590's, and was justified with being "a matter of much importance [...] to obtain with this fortress all the good effects that are necessary for the safety of the village", as acknowledged by the King in a document sent to Frutuoso Barbosa. During its first decade of construction, it was destroyed and rebuilt several times due to the indigenous invasions (LIVRO DO TOMBO, 1948; PINTO, 1977).

As previously mentioned, the primitive Fort of Cabedelo was built in taipa and, subsequently, in wood and taipa, and, by the middle of the $17^{\text {th }}$ century, it was in a very poor state of conservation. Between the end of the $17^{\text {th }}$ century and the beginning of the $18^{\text {th }}$ century, its reconstruction slowly restarted and, in the following century, its original materials were replaced with stone and lime. Gradually, the walls, the gunpowder house, the body of the guard, the barracks, the Governor's house, the vaults of the doors, the strings of the walls, among other elements, were finished. The parapets, stakes, platforms and esplanades were progressively recovered, although the natural agents, as the constant maritime invasions during flood seasons, forced the construction of a stone pier to try to contain them. In 1688, the Governor of Paraíba details, in a letter sent to King Dom Pedro II (A.H.U.-ACL_CU_014, Cx 1, doc. 158, fl 6), the situation in which the fortress was

[...].today, it is finished, with the sea eating the whole of it, and I continue to walk with the soldiers carrying the 'fachina', and putting the stone on the part of the bridge, which is from where the sea makes the bigger damage, and it has taken two platforms, and it puts is so shallow, that to enter the fortress it does not lack a ember; it does not possess wattle and daub; the parapets are shallow, and the other three platforms are in such a way, that one cannot shoot any artillery from them, due to being rotten [...].

During the Dutch domain (1634-1654), the fort was restructured and solidified, becoming a fortress, although it was still made of wood and taipa, presenting "moat, trench, parapet, fourteen bronze cannons and forty-two of iron" (BARLEUS, 1940, p. 170), apart from the addition of bulwarks, with half-adjacent bulwarks connected by a tenaille (CEULLEN et al., 2004). 
Much of this ruin is justified by the location of the fort, in the Restinga of Cabedelo, likely to suffer the loss of stability of the walls, causing abrasion. A situation that caused concern in the Captaincy. One of the answers to these concerns, dated from 1709, reports the situation in the fort, in which the King points out that

You have a defect in the principle, whose remedy will be costly, but it is necessary to avoid the danger of the probable ruin, considering the crash of the sea on the wall, that could begin with the fact of the foundation is not made on grid, due to this and more that is lacking, before we need an Engineer and consignations.

In a new letter exchanged between the governor of Paraíba, Colonel Luís António de Lemos de Brito and King Dom José I (I.H.G.P.-Documentos coloniais manuscritos-Ordens régias-Livro 02, folha 03), in 1755, the problem persisted, because

[...] it is certain that the fortress of the Cabedello was not made to have an aquatic moat because it was made very far from the sea; but with the continuation of the years the waters will extend to its limits and will eat the land, which today hits its wall, on the high tide or during 'agoas vivas'.

In the fieldwork carried out in this project, two rock types were identified as components of the fortress: limestone from the Gramame Formation (Maastrichtian) and ironstone from the Barreiras Formation (Pliopleistocene), sometimes organised according to a predefined pattern (figure 6a), and others chaotically mixed. Locally, on some walls composed of limestone blocks, a strip of ironstone marks the wall with its dark colour. It is possible to consider that this line was inserted merely for aesthetic purposes, since it has no functionality (figure 6b). Probably due a partial anastylosis recomposition process, more recent materials, such as gneisses and granites, were later introduced.

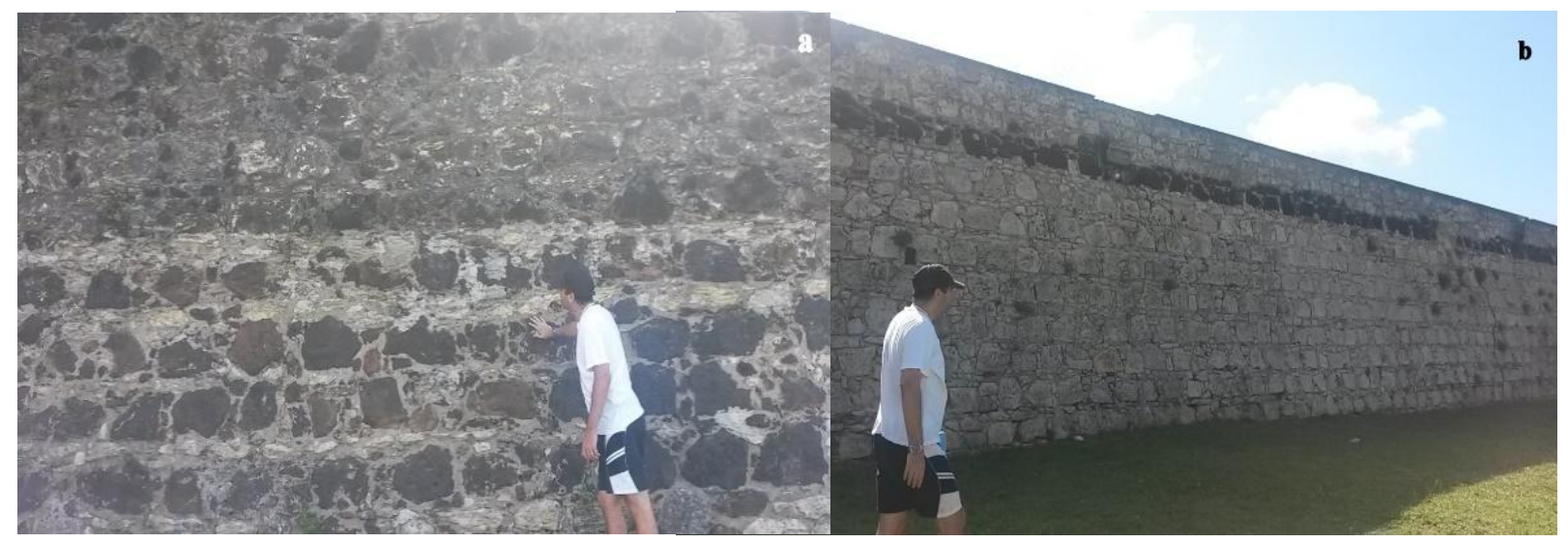

Figure 6: Elements of ex situ geodiversity present in the Fortress of Cabedelo. (a) Wall composed primarily of ferruginous sandstones; (b) Wall with limestone blocks and an upper line with Ferruginous sandstones. Photos: Ingrydy Pereira.

The nearest presence of ironstone is at the foot of the Cabo Branco Cliff, about $26 \mathrm{~km}$ away, going along the waterfront. Most likely, this material, or some further south, as in Jacarapé, was the place of origin of this ironstone. In turn, the limestone was extracted from the outcrops present in the northern slopes of the emerging city and transported through flat-bottomed barges, which resorted to paid indigenous labour. These boats were able to navigate the shallow canals of the Paraíba River and were the usual means of rock transportation to the fortress (PEREIRA, 2019). One of these quarries, located in the 'Manoel Gonçalvez Salt Mine' was mentioned in a historical document, but its origin was not found and should be located in the Paraíba River downstream, as the other outcrops in the city that provided the rock for the fortress and were reported in this document. In some blocks of the fortress, the features in ironstone and limestone are similar to those found in the areas mentioned above, such as texture characteristics and plane-parallel stratification (figure 7a), in the ironstone, and bioturbation structures caused by the ichno-species Thalassinoides isp (figure 7b), in the limestone. A block with dissolving features was found forming a 'honeycomb' type microform of limestone pavement, not present in the work area until then (figure 7c). This type of feature, according to Rodrigues et al. (2007) is associated with the mechanical and chemical action of the raindrops. The ironstone was also carved and placed in front of the door of the fortification, according to a specimen exhibited in the fort museum (figure 7d). 


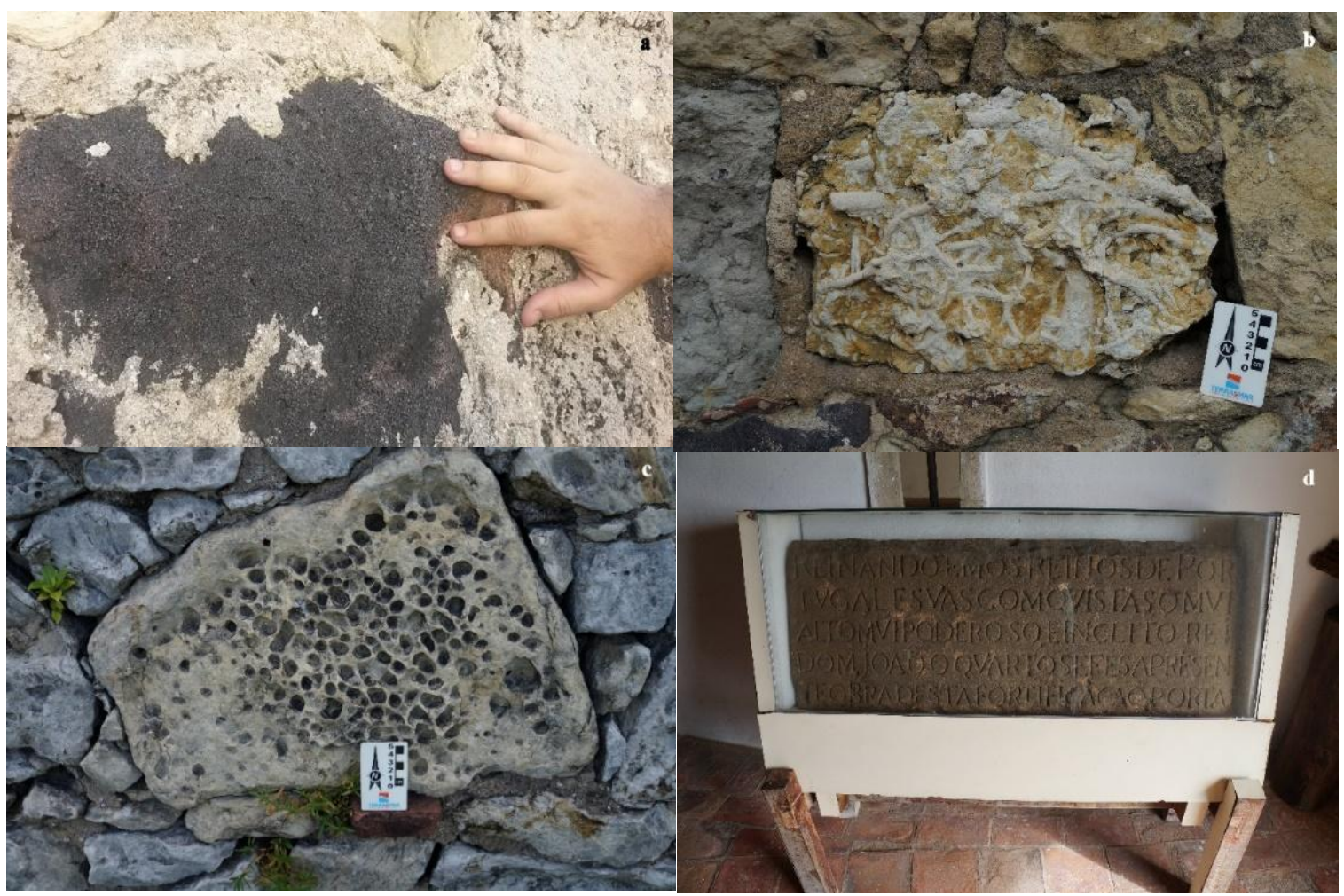

Figura 7: Detail of the rocks from the walls of Fortaleza de Cabedelo. (a) Ferruginous sandstone; b) Limestone of the Gramame Formation with ichnofossils; (c) Honeycomb lapies; d) Carved Ferruginous sandstone. Photos: the author.

The limestone used in the columns of the 'Governor's House' show a greater amount of earth elements, especially grains of sand, which are easily detected through the touch than most of the limestone blocks present in the walls of the fortress. This characteristic allows us to state that these limestone blocks were removed at the top of a carbonate sequence, indicative of a shallower environment, and that this contribution was caused by tectonic factors, since, in the majority of the limestone and Maastrichtian marlstone, present in the Gramame Formation, there is practically no sedimentary material present (BARBOSA, 2007).

\subsection{4th Stop: Jacaré Beach}

The Jacaré Beach consists of a river beach on the right bank of the Paraíba River, about $7 \mathrm{~km}$ from the mouth, over the Holocene sediments of the Restinga of Cabedelo. From this Place of Interest, there is a wide view over the river-marine plain of the Paraíba River, the largest in the State, its brackish water deposits, which occupy the banks of the river, reaching $20 \mathrm{~km}$ estuary inward, and the river terraces of the left bank. The role played by the tectonic control over the lower course of the river stands out.

The Paraíba River, also known as the Paraíba do Norte River, is the main river of the basin with the same name and the most extensive river of the Paraíba Region. The Paraíba River Basin is the second largest basin in Paraíba, inferior only to the Piranhas River Basin.

A problem that occurs in its medium and high course and that affects its estuary is silting, resulting from inadequate agricultural practices, associated with the sugarcane cultivation and the intense deforestation of riparian forests. Large volumes of sediments reach the lower course of the river, originating from the erosion of nearby slopes. As these sediments are deposited, the river capacity decreases. The result of the accumulation of these sediments is the formation of sandbanks and islets, which reduce the width and depth of the river and make its waters more turbid.

Through oral information provided by local residents, the beach has this name because, in the 1960s, the landing of seaplanes in the area generated, with the waves, the shape of an alligator in the water, hence the name given to the place (Jacaré = Alligator). However, in historical documentation dated from 1630, it was found the description of "a stop that is called Jacare [...] because everything else of one part and the other are mangroves and thick trees with the same river where one cannot disembark out of respect for the many arms that make the river muddy", which, in other words, may indicate that the name has an indigenous etymology. 
This estuary, where the Place of Interest is located, is a river-marine plain, whose semidiurnal tides do not exceed $2.80 \mathrm{~m}$ (SASSI, 1991) and river waters inundate its valleys, during flood seasons, with the accumulation of sediments, particularly argillaceous. This accumulation, whose granulometry is related with the ability of the river to transport it and that periodically appears at low tides, attests to the relatively shallow and flat nature of its channel, especially on the right bank, Bispo Island, mapped in the $17^{\text {th }}$ century iconography. The sandbanks presented serious problems to the sailors who ventured into their waters in the initial settlement of the Parahyba captaincy. This situation justifies the etymology of the word 'Parahyba', which, originating from the Tupi-Guarani, means 'to - river, $y b a$ - bad', which means a river difficult for navigation (MACHADO, 1993).

As it approaches its mouth, the Paraíba River widens, forming an estuarine complex with a valley bottom that gives origin to the river-marine plain of the Paraíba River, with its fluvial terraces, filled by a dense anastomosed drainage network that flows into the river (figure 8). The accumulation of fine-grained sediment, combined with the action of periodic tides, has formed an ecosystem of large mangroves, which practically inhabit the majority of the tributaries of the Paraíba River.

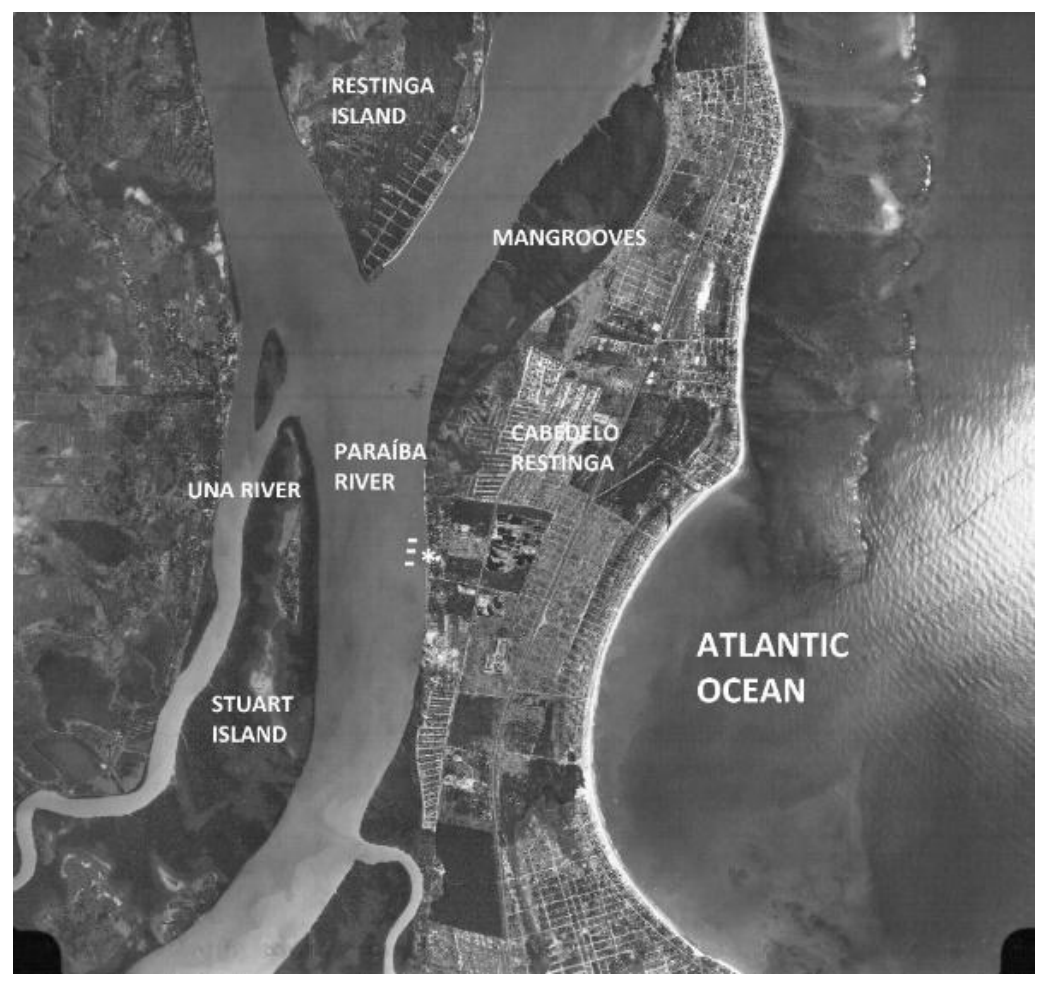

Figure 8: Aerial shot of Jacaré Beach. Evident is the wide range of mangroves, which narrow in the beach area, as a result of urbanization and deforestation. The river terraces on the opposite bank were occupied by sugar cane. Legend: *- Place of interest. Scale 1: 50,000. Photo: Incra/Terrafoto (1989).

The ecosystem of the mangroves of the Paraíba River estuary is the most impressive in the state. This relatively homogeneous, arboreal, halophilic and uniform plant formation is characterized by the mangrove soils, rich in decomposing organic matter, consisting of vegetable debris (leaves, roots and stems) and material (shell and organic matter), with fine grain size and high salinity, associated with the flow and back flow of tides.

The dynamics and energy of deposition are low, creating marshy zone underlain by sandy-argillaceous sediments rich in organic matter and shells, where on a typical flora has developed, adapted to the mixture of fresh and salty waters and low oxygenation. Small animals, especially crustaceans, molluscs and fish (which go to feed and reproduce) have transformed the fragile ecosystem into an ecological nursery, which is also important for the quality of life of thousands of families who earn their living with crab fishing. The mangroves are protected by the Forest Code (BRASIL, 2012).

The great demographic density in its estuary is generating a disfigurement of its landscape, through human occupation and the necessary works for its settlement. There is a disrespect for the mangroves that are used as garbage and sewage deposits by the carcinocultura (shrimp farming), industry and deforested to be converted in construction sites for buildings. The compressibility of its argillaceous soil, a consequence of the weight of the buildings, induces the subsidence of the land, something that already occurs in other places 
in Brazil and the world. The Manaíra Shopping, the Forrock and the Bus Station of João Pessoa are some examples of constructions in mangrove areas. In the specific case of the bus station, the consequences are already visible, with the sinking of part of the bus parking lot, where the departure and arrival boxes of the vehicles are located. The largely irregular occupation of the Jacaré Beach should be contained so that the fortune of the area does not follow in the footsteps of those mentioned above.

In addition, there is the intense extraction of sand for building construction, on the north side of the road that gives access to the Jacaré Beach, forming a depressed area filled by rainwater, which originate anthropogenic lagoons.

The role of the Paraíba River in the conquest of the Parahyba Captaincy stands out, whether from a strategic point of view, through the installation of a defensive triangle of fortifications, or in the consolidation, on its river terraces, of countless sugar cane mills, important for the expansion of the captaincy in accordance with the overseas interests (NIEUHOF, 1942). Every day, several chalanas depart from the pier of the Jacaré Beach and make a trip to the mouth of the river, making a journey in an area of crucial historical, geoscientific and ecological importance, which denotes the geotouristic importance of the region.

Thus, the Place of Interest can be considered a geoheritage asset of the municipality, due to the exceptional functional value (ecological) and the very high aesthetic, scientific, cultural and economic values.

Since the total length of this route is about $25 \mathrm{~km}$, it can be travelled in one day with a vehicle. It is suggested to start it on the sandbank of Areia Vermelha, in front of Camboinha Beach, early in the morning. The tendency is to enjoy the place in the morning, returning to the beach at the end of it. After lunch, the visit proceeds to the Cultural Heritage of the itinerary: the Ruins of Almagre and the Fortress of Cabedelo. The itinerary finishes at the Jacaré Beach to observe the sunset, which usually occurs at approximately $5: 15 \mathrm{pm}$ all year round, depending on the time of year.

\section{Conclusions}

The role of geotourism is to bring the public closer to the geoheritage and the cultural heritage of the area visited, through geointerpretation strategies designed for the public that visits it. Thus, the tourist interaction with the abiotic environment will sensitize the tourist/geotourist to perceive it from a new point of view and to promote the appreciation of geodiversity and geoheritage. This interaction will also serve as a tool for the education of the local population and tourists and disseminate Geosciences beyond classrooms, with the purpose of preserving and managing this geoheritage significance and associated cultural heritage.

The main geoproduct obtained from the mapping of the places of interest was the Geotouristic Map, with its itinerary. Its interdisciplinary character and geoeducational material play the role of an awareness creator and sensitizer towards the geoconservation and the promotion of Geosciences.

The holistic vision allowed a range of new interdisciplinary discussions to be open, by enabling cultural experiences distinct from traditional ones and by rediscovering its cultural roots, a sense of place and a reverence for the natural world, achieved through the recognition and celebration of the creativity associated with the abiotic heritage.

The 'sun and sea' is the main tourist attraction of the region, allied in a secondary level to a rich history and culture that neglects the latent geotouristic potential. The geotouristic itineraries also serve to promote geotourism as an asset, inserting in the traditional tourist context information about the previously forgotten abiotic environment. Therefore, mass tourism will be promoted for a niche tourism, becoming more sustainable under the environmental bias.

This article aims at putting into practice, as a final product, a geotouristic itinerary in the Cabedelo Municipality. It proposes to promote the abiotic environment, a trigger for the development of a geoconservationist awareness and a facilitator of the local economy, necessary for the role that the abiotic environment has as a record of current and past geOenvironments, influenced by various elements and influencer of many others. In addition, the geotouristic itinerary can be used not only for tourist purposes, but also for education, and all the information presented is a way of promoting Geosciences, especially Geology, to the local communities and tourists. 
Acknowledgments

The authors would like to thank the Centre for Studies in Geography and Spatial Planning (CEGOT) for the support regarding the translation costs.

\section{References}

ALHEIROS M.; FERREIRA, M.G.V.X.; LIMA FILHO, M. (1990). Mapa geológico do Recife. Convênio Carta Geotécnica da cidade do Recife FINEP/ LSI- DEC- UFPE (Mapa, escala 1: 25.000).

BARBOSA, J, (2007). A deposição carbonática na faixa costeira Recife- Natal: aspectos estratigráficos, geoquímicos e paleontológicos. PhD Thesis, Universidade de Pernambuco, Recife, Brazil.

BARBOSA, L.M.; BITTENCOURT, A.; DOMINGUEZ, J.; MARTIN, L. (1986). Tue Quaternary coastal deposits of the State of Alagoas: influence of the relative sealevel changes. In: RABASSA, J. (ed). Quaternary of South America and Antartic Peninsula. Balkema Publ., 4: 269- 290.

BARLEUS, G. (1940). História dos feitos recentes praticados durante oito anos no Brasil e noutras partes sob o governo do ilustríssimo João Maurício Conde de Nassau. Rio de Janeiro: Imprensa Nacional, 1940. http:// www2. senado.leg.br /bdsf/ bitstream/ handle/id/1109/O\%20 Brasil\%20 holandes.pdf? sequence=1, pertencente ao Senado brasileiro. Acessed 20 June 2014.

BARRETO, A.; ASSIS, H.; BEZERRA, F.H.R.; SUGUIO, K. (2010). Arrecifes, a calçada do mar de Recife. Publicado online em 27 de outubro de 2010. http://sigep.cprm.gov.br/sitio040/sitio040_impresso.pdf. Acessed 17 April 2018.

BITTENCOURT, A,; MARTIN, L.; VILAS BOAS, G. FLEXOR, J. (1979). The Marine Formations of the coast of the State of Bahia, Brazil. In: SUGUIO, K.; FAIRCHILD, T.; MARTIN, L;. FLEXOR, J. (Eds.). Proceedings of the International Symposium on Coastal Evolution in the Quaternary. São Paulo, 232253.

BITTENCOURT, A.; MARTIN, L.; DOMINGUEZ, J.; FERREIRA.; Y. (1983). Evolução paleogeográfica quaternária da costa do estado de Sergipe e da costa sul do Estado de Alagoas. Revista Brasileira de Geociências, 13 (2): 94- 95.

BRANNER, J.C. (1904). The stone reefs of Brazil, their geological and geographical relations, with a chapter on the coral reefs. Bulletin of the Museum Comparative Zoology at Harvard College, Cambridge, vol. 44, n. 7, p. 285.

BRASIL (2012). Código Florestal Brasileiro. Lei Federal $\mathrm{n}^{\circ} 12.651$, de 25 de maio de 2012. http://www.planalto.gov.br/ccivil 03/ ato2011-2014/2012/lei/112651compilado.htm. Acessed 15 July 2021.

BRILHA, J. (2005) Património Geológico e Geoconservação, a conservação da natureza na sua vertente geológica. Braga: Palimage Editores.

CEULlEN, M.; DUSSEN, A.; NASSAU, J. M.. "Breve discurso sobre o Estado das quatro capitanias conquistadas, de Pernambuco, Itamaracá, Paraíba e Rio Grande, situadas na parte setentrional do Brasil (1638)". In: MELLO, José Antonio Gonsalves de (org.). Fontes para a história do Brasil Holandês. Volume I. $2^{a}$ edição. Recife: Companhia Editora de Pernambuco, 2004, p. 77-129.

DOMINGUEZ, J.M.; BITTENCOURT, A.C.; LEÃO, Z.M.; AZEVEDO, A.E. (1990). Geologia do quaternário costeiro do Estado de Pernambuco. Revista Brasileira de Geociências, 20 (1): 208- 215.

FURRIER, M. (2007). Caracterização geomorfológica e do meio físico da Folha de João Pessoa- 1: 100.000. PhD Thesis, Universidade de São Paulo, São Paulo, Brazil.

GUIMARÃES, T.; MARIANO, G.; BARRETO, A.; SÁ, A. (2016). Beachrocks of Southern Coastal Zone of the State of Pernambuco (Northeastern Brazil): Geological Resistance with History. Geoheritage, 9: 1-9. 
HARTT, C.F. (1870). Geology and physical geography of Brazil. Boston, Fields, Osgood and Co.

Instituto Fecomercio de Pesquisas Econômicas e Sociais da Paraíba - IFEP (2014). Pesquisa Anual do Desempenho do Turismo na Região Metropolitana de João Pessoa-Pesquisa realizada junto aos turistas, ano 2014. www.fecomercio-pb.com.br/index. Acessed 24 April 2015.

Instituto Brasileiro de Geografia e Estatística - IBGE (2010). Sinopse do Censo Demográfico 2010. http://www.censo2010.ibge.gov.br/sinopse/index.php?dados=6\&uf=00. Acessed 13 April 2015.

KOMAR, P.D. (1998). Beach processes and sedimentation. $2^{\mathrm{a}}$ ed. USA: Prentice Hall.

Livro do Tombo do Mosteyro de Sam Bento da Parahyba (1948). Recife: Imprensa Oficial, Livro 2.

MABESOONE, J. (1964). Origin and age of the sandstone reefs of Pernambuco (Northeastern Brazil).

Journal of Sedimentology, 34 (4): 715- 726.

MACHADO, J.P. (1993). Dicionário Onomástico Etimológico da Língua Portuguesa. $2^{\text {a }}$ ed., vol. 2, Livros Horizonte: Lisboa.

MANSUR, K.L. (2010). Diretrizes para Geoconservação do Patrimônio Geológico do Estado do Rio de Janeiro: o caso do Domínio Tectônico Cabo Frio. PhD Thesis, Universidade Federal do Rio de Janeiro, Rio de Janeiro, Brazil.

MARTIN, L.; FLEXOR, J.M.; VILAS BOAS, G.S.; BITTENCOURT, A.; GUIMARÃES, M.M.M. (1979). Coube de variations niveau relatif de la mera u cours dês 7.000 dernieres amnées sur um secteur homogéne Du litoral bréseilien (Nord de Salvador- Bahia). In: SUGUIO K.; FARCHILD, T.; Martin, L.; Flexor, J.M. (Eds). International Symposium on Coastal Evolution in the Quaternary, 1979, São Paulo. Proceedings... São Paulo: ABEQUA, 264- 274.

NIEUHOF, J. (1942). Memorável viagem marítima e terrestre ao Brasil. São Paulo: Livraria Martins.

OLIVEIRA, C.M. (2002). Em torno do uso turístico do patrimônio histórico: o caso da Igreja de Nossa Senhora de Nazaré de Almagre (Cabedelo-PB). Veredas Revista Científica de Turismo, ano 1, n. 1.

PEREIRA, L.S, (2019) Mapeamento do geopatrimônio e do patrimônio cultural da região de João Pessoa (Paraíba) para fins de geoturismo urbano e costeiro. PhD Thesis, Universidade de Coimbra, Coimbra, Portugal.

PEREIRA, L.S.; AMARAL, J. (2014) Geoturismo urbano: análise da tipologia geológica e cultural da capitania da Parahyba. Cadernos de Estudo e Pesquisa em Turismo, 3 (3): 239- 264.

PEREIRA, L.S.; VIEIRA, K.G.; OLIVEIRA, B.L. (2013). The look on theurban geoheritage of João Pessoa City: a guide to resignify rocks-document. Poster session presentation at the meeting of International Conference on Geography and Geosciences. Paris, France.

PEREIRA, L.S.; CARVALHO, D.M.; CUNHA, L.S. (2019) Methodology for the Semi-quantitative Evaluation of Geoheritage Applied to Coastal Geotourism in João Pessoa (Paraíba, Northest Brazil). Geoheritage 11, 1941-1953. doi:10.1007/s12371-019-00417-7

PINTO, I. (1977) Datas e Notas para a História da Paraíba. João Pessoa: Universitária/ UFPB.

RODRIGUES, M.L.; CUNHA, L.; RAMOS, C.; PEREIRA, A.R.; TELES, V.; DIMUCCIO, L. (2007). Glossário ilustrado de Termos Cársticos. Maria Luisa Rodrigues (coord.). Lisboa: Ed. Colibri.

SASSI, R. (1991) Phytoplankton and environmental factors in the Paraíba do Norte River estuary, northeastern Brazil: composition, distribution and quantitative remarks. Boletim do Instituto de Oceanografiada USP, 39 (2): 93- 115. 
SILVA, M.L.; DANTAS, T.B.; NASCIMENTO, M.A.; VIEIRA, M.M. (2017). Os corpos de arenitos praiais que sustentam o Forte dos Reis Magos, principal construção histórica da cidade de Natal, RN. Geociências, 36 (3): 497-508.

SUGUIO, K. (1992). Dicionário de geologia marinha. São Paulo: T. A. Queiroz.

SUGUIO, K,; MARTIN, L. (1978). Quaternary marine formations of the State of São Paulo and Southern Rio de Janeiro. In: International Symposium on Coastal Evolution in the Quaternary, 1, 1978. São Paulo. Special Publication, v. 1, 55 p.

SUGUIO, K.; BARRETO, A.M.F.; OLIVEIRA, P.E.; BEZERRA, F.H.R.; VILELA, M.C. (2013). Indicadores de variações holocênicas do nível do mar ao longo da costa dos estados de Pernambuco e Paraíba, Brasil. Revista do Instituto de Geociências-USP, 13 (4): 14-152.

\section{Historical documentation}

A.H.U.-ACL_CU_014, Cx 1, doc. 158, fl 6

I.H.G.P.-Documentos coloniais manuscritos-Ordens régias-Livro 02, folha 03.

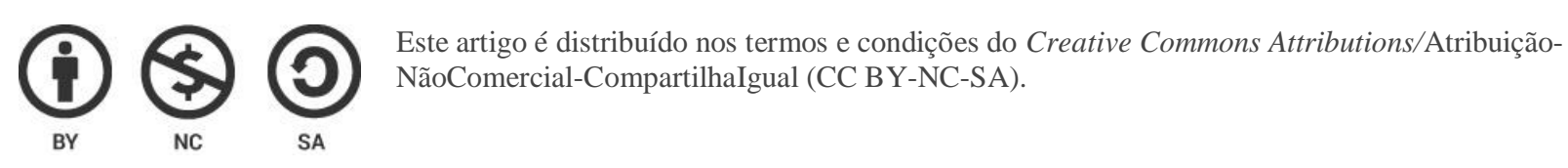

